\title{
A novel coral-like garnet for high-performance PEO-based all solid-state batteries
}

\author{
Jun Cheng ${ }^{1}$, Guangmei Hou ${ }^{2}$, Qing Sun ${ }^{2}$, Qiong Chen ${ }^{1}$, Deping Li ${ }^{*}$, Jianwei Li $^{2}$, Zhen Zeng ${ }^{2}$, Kaikai Li $^{1}$, \\ Qunhui Yuan ${ }^{1}$, Jiajun Wang ${ }^{3}$ and Lijie $\mathrm{Ci}^{1,2^{*}}$
}

\begin{abstract}
As one of the most promising next-generation energy storage devices, the lithium-metal battery has been extensively investigated. However, safety issues and undesired lithium dendrite growth hinder its development. The application of solid-state electrolytes has attracted increasing attention as they can solve safety issues and show great potential to inhibit the growth of lithium dendrites. Polyethylene oxide (PEO)-based electrolytes are very promising due to their enhanced safety and excellent flexibility. However, they suffer from low ionic conductivity at room temperature and cannot effectively inhibit lithium dendrites at high temperatures due to the intrinsic semicrystalline properties and poor mechanical strength. In this work, a novel coral-like $\mathrm{Li}_{6.25} \mathrm{Al}_{0.25} \mathrm{La}_{3} \mathbf{Z r}_{\mathbf{2}^{-}}$ $\mathrm{O}_{12}$ (C-LALZO) is synthesized to serve as an active ceramic filler in PEO. The PEO with LALZO coral (PLC) exhibits increased ionic conductivity and mechanical strength, which leads to uniform deposition/stripping of lithium metal. The $\mathrm{Li}$ symmetric cells with PLC do not cause a short circuit after cycling for $1500 \mathrm{~h}$ at $60^{\circ} \mathrm{C}$. The assembled $\mathrm{LiFePO}_{4} / \mathrm{PLC} / \mathrm{Li}$ batteries display excellent cycling stability at both 60 and $50^{\circ} \mathrm{C}$. This work reveals that the electrochemical properties of the composite electrolyte can be effectively improved by tuning the microstructure of the filler, such as the C-LALZO architecture.
\end{abstract}

Keywords: coral-like garnet, composite solid-state electrolyte, all-solid-state battery

\section{INTRODUCTION}

With the ever-growing demand for efficient and rechargeable energy storage, lithium-ion batteries with high energy density and long cycling life have attracted great attention [1-5]. Lithium ( $\mathrm{Li}$ ) metal has been extensively considered as the most promising anode due to its high theoretical specific capacity $\left(3860 \mathrm{~mA} \mathrm{~h} \mathrm{~g}^{-1}\right)$ and the lowest electrode potential $(\sim 3.04 \mathrm{~V} v s$. the standard hydrogen electrode), and the corresponding lithium-metal batteries (LMBs) have been studied for several decades [6-8]. However, many barriers hinder the practical application of LMBs [9-12]. In traditional LMBs with liquid organic electrolytes, the side reactions and uneven plating/ stripping of lithium during cycles cause undesired Li dendritic growth or mossy Li generation, which can lead to internal shortcircuiting or even an explosion [13-15].

The application of solid-state electrolytes in LMBs has attracted increasing attention because they can solve the safety issue and effectively prevent the formation of an unstable solidstate electrolyte interphase (SEI) $[16,17]$. In addition to inorganic ceramic solid electrolytes, solid polymer electrolytes, such as polyethylene oxide (PEO), are becoming increasingly promising due to their excellent flexibility $[18,19]$. However, because of the intrinsic semicrystalline properties and poor mechanical strength, PEO electrolyte suffers low room-temperature ionic conductivity and insufficient capability for inhibiting lithium dendrites [20]. Therefore, a great number of approaches have been adopted to overcome these issues [21-25]. Compositing ceramic fillers within the PEO matrix is an effective approach to improve the ionic conductivity and mechanical properties $[26,27]$. The existence of fillers leads to the decreased crystallinity of PEO, which further improves the ionic conductivity. Ceramic fillers can be divided into two categories: inactive ceramic fillers and active ceramic fillers which can serve as ion conductors [28]. Adding inactive ceramic fillers, such as $\mathrm{Al}_{2} \mathrm{O}_{3}$ [29], $\mathrm{ZrO}_{2}$ [30], and $\mathrm{SiO}_{2}$ [27] to form solid composite polymer electrolytes (CPEs) has been proved to be a valid strategy. However, the low ionic conductivity is still a tricky issue. Compared with inactive ceramic fillers, adding inorganic solid-state electrolytes to the PEO matrix can be more effective to improve the ionic conductivity further since they can provide additional fast paths for lithium-ion transport. In previous studies, $\mathrm{Li}_{7} \mathrm{La}_{3} \mathrm{Zr}_{2} \mathrm{O}_{12}$ (LLZO) [31,32], $\mathrm{Li}_{1.5} \mathrm{Al}_{0.5} \mathrm{Ge}_{1.5}\left(\mathrm{PO}_{4}\right)_{3}$ (LAGP) [33], and $\mathrm{Li}_{1+x} \mathrm{Al}_{x} \mathrm{Ti}_{2-x}\left(\mathrm{PO}_{4}\right)_{3}$ [34] have been demonstrated to be useful not only to improve the ionic conductivity of PEO electrolyte but also to increase its strength. The CPE can also effectively suppress the growth of undesired lithium dendrite. Besides, the interfacial resistance between electrolyte and lithium metal anode can be effectively reduced by compositing active fillers [35]. For instance, Chen et al. [35] reported a CPE with

\footnotetext{
${ }^{1}$ State Key Laboratory of Advanced Welding and Joining, School of Materials Science and Engineering, Harbin Institute of Technology (Shenzhen), Shenzhen 518055, China

${ }^{2}$ Research Center for Carbon Nanomaterials, Key Laboratory for Liquid-Solid Structural Evolution \& Processing of Materials (Ministry of Education), School of Materials Science and Engineering, Shandong University, Jinan 250061, China

${ }^{3}$ MIIT Key Laboratory of Critical Materials Technology for New Energy Conversion and Storage, School of Chemistry and Chemical Engineering, Harbin Institute of Technology, Harbin 150001, China

* Corresponding authors (emails: lideping@hit.edu.cn (Li D); cilijie@hit.edu.cn (Ci L))
} 
$\mathrm{Li}_{6.4} \mathrm{La}_{3} \mathrm{Zr}_{1.4} \mathrm{Ta}_{0.6} \mathrm{O}_{12}$ particles as the filler and found it favorable to suppress the growth of $\mathrm{Li}$ dendrites. Zhao et al. [36] chose four types of LAGP with different particle sizes as active fillers to fabricate PEO/LAGP CPEs. The results indicate that LAGP particles provide a positive effect to enhance the ionic conductivity of the CPE.

Besides ceramic particles, ceramic nanowires and threedimensional (3D) ceramic frameworks have attracted much interest due to their obvious increase in ionic conductivity [37]. Wan et al. [38] applied LLZO nanowires as the filler to modify PEO and verified that LLZO nanowires in the PEO matrix can efficiently enhance the ionic conductivity and mechanical properties of the CPE. The addition of LLZO nanowires can also contribute to the uniform deposition of lithium during the cycle process. Gong et al. [39] reported CPEs with a template-derived 3D ceramic textile, exhibiting an enhanced electrochemical performance and thus demonstrating the advantages of $3 \mathrm{D}$ lithium conductive ceramics in CPEs.

Ceramic nanoparticles [40], nanowires [34,41,42], nanosheets [43], and 3D frameworks [44-46] as the filler in PEO have been widely studied, and their positive effects on the ionic conductivity and mechanical properties of CPE have been demonstrated. Herein, we report the synthesis of a coral-like $\mathrm{Li}_{6.25} \mathrm{Al}_{0.25} \mathrm{La}_{3} \mathrm{Zr}_{2} \mathrm{O}_{12}$ (C-LALZO) electrolyte via a sol-gel method with graphene oxide (GO) as nucleation additives. The PEObased CPE with C-LALZO (PLC) as the active filler presents excellent electrochemical performance. Garnet LALZO has high ionic conductivity and air stability at room temperature as well as good electrochemical stability against lithium metals [47]. Furthermore, the advantages of C-LALZO in enhancing the conductivity and inhibiting the growth of lithium dendrites in CPEs were investigated. The assembled $\mathrm{LiFePO}_{4}$ (LFP)/PLC/Li all-solid-state battery demonstrates excellent cycling stability and rate performance at both 50 and $60^{\circ} \mathrm{C}$. C-LALZO can further enhance the ionic conductivity of CPEs due to the formation of continuous and fast Li-ion transfer pathways, which can effectively promote the uniform deposition of lithium metal without the growth of lithium dendrites. The decomposition potential of $\mathrm{CPE}$ is widened to around $5.2 \mathrm{~V}$ at $50^{\circ} \mathrm{C} v s$. metallic $\mathrm{Li}$, which means the CPE could match cathode materials with higher working potentials such as $\mathrm{LiNi}_{1 / 3} \mathrm{Co}_{1 / 3} \mathrm{Mn}_{1 / 3} \mathrm{O}_{2}$ (NCM) and $\mathrm{LiCoO}_{2}$ (LCO). This work provides a facile sol-gel method to fabricate C-LALZO, and an all-solid-state battery with its CPE achieves outstanding cycling stability and rate performance.

\section{EXPERIMENTAL SECTION}

\section{Preparation of LALZO branches and corals}

Element $\mathrm{Al}$ was selected to stabilize the cubic garnet phase. Stoichiometric amounts of $\mathrm{LiNO}_{3}, \mathrm{La}\left(\mathrm{NO}_{3}\right)_{3} \cdot 6 \mathrm{H}_{2} \mathrm{O}, \mathrm{C}_{20} \mathrm{H}_{28} \mathrm{ZrO}_{8}$, and $\mathrm{Al}\left(\mathrm{NO}_{3}\right)_{3} \cdot 9 \mathrm{H}_{2} \mathrm{O}$ (purchased from Aladdin) were dissolved in a mixed solvent (ethanol:deionized water $=3: 1$, by volume), followed by adding citric acid (citric acid:metallic cation $=2: 1$ in mole ratio) as the complexant. Additional $\mathrm{LiNO}_{3}(20 \mathrm{wt} \%)$ was added to compensate for the lithium loss during calcination. Afterward, the solution was stirred on a hot plate to evaporate the solvent and form a tawny solid precursor. To obtain the cubic phase branch-like LALZO (B-LALZO), the precursor was first heated at $200^{\circ} \mathrm{C}$ for $2 \mathrm{~h}$ under vacuum to remove the residual solvent and then calcined at $800^{\circ} \mathrm{C}$ for $5 \mathrm{~h}$ in air. The preparation of C-LALZO was the same as that of B-LALZO except for the addition of $\mathrm{GO}\left(\mathrm{LiNO}_{3}: \mathrm{GO}=16\right.$ by weight $)$ to the precursor solution as the nucleation sites.

\section{Preparation of CPE}

The PLC and PLB (PEO with B-LALZO) CPEs were fabricated by the solution-casting method. The PEO $\left(M_{\mathrm{w}}=600,000\right.$, Sigma $)$ and lithium bis(trifluoromethylsulfonyl)imide (LiTFSI) (Aladdin, 99\%) were added to acetonitrile with a mole ratio of $\mathrm{EO}: \mathrm{Li}=$ 8:1. After stirring for several hours, B-LALZO or C-LALZO was added to the aforementioned solution and stirred for several hours. The homogeneously suspended composite solution was poured into Teflon molds and dried in an argon-filled glovebox. The obtained composite solid electrolyte membrane was further dried at $60^{\circ} \mathrm{C}$ for $10 \mathrm{~h}$ in a vacuum oven to remove the residual solvent and then punched into certain sizes and shapes.

\section{Characterization of LALZO and CPE}

X-ray diffraction (XRD) patterns of the B-LALZO, C-LALZO, and CPEs were recorded with an X-ray diffractometer (Bruker D8 Advance, Germany) using $\mathrm{Cu} K a$ radiation $(\lambda=0.154 \mathrm{~nm})$ in an angular range of $10^{\circ}-90^{\circ}$ at a power of $600 \mathrm{~W}(40 \mathrm{kV}, 15 \mathrm{~mA})$. The morphology and interplanar spacing of LALZO materials were characterized using a scanning electron microscope (SEM, Phenom pro) and a high-resolution transmission electron microscope (HRTEM, JEOL JEM-2100). Thermogravimetric analysis (TGA) was performed with a Mettler-Toledo TGA2 Thermo Analyzer from 30 to $900^{\circ} \mathrm{C}$ at a ramping rate of $5^{\circ} \mathrm{C} \mathrm{min}^{-1}$ under Ar protection. The Fourier transform infrared (FTIR) spectra were obtained on a Bruker Tensor 37.

\section{Electrochemical characterization of solid CPE}

CR2032 cells were assembled by sandwiching the electrolyte between two stainless steel (SS) sheets to test the ionic conductivity of the solid CPE with different LALZO contents using electrochemical impedance spectroscopy (EIS). The measurements were carried out in a frequency range from $1 \mathrm{MHz}$ to $0.1 \mathrm{~Hz}$ from 25 to $70^{\circ} \mathrm{C}$ on a Metrohm-Autolab B.V. electrochemical station. The electrochemical stability of the composite solid electrolyte was investigated via linear sweep voltammetry (LSV) which was applied to a cell with an SS plate as the working electrode and Li metal as the counter and reference electrodes. The applied potential ranges from 2.5 to $6.0 \mathrm{~V}$ at a scanning rate of $0.1 \mathrm{mV} \mathrm{s}^{-1}$ at $60^{\circ} \mathrm{C}$. The assembled Li/CPE/Li cells were galvanostatically cycled at current densities of 0.02 and $0.05 \mathrm{~mA} \mathrm{~cm}^{-2}$ on a Land-CT2001A battery testing system for interfacial stability testing. The LFP/PLB/Li and LFP/PLC/Li cells were assembled for the galvanostatic intermittent titration technique (GITT) measurement. The assembled all-solid-state cells were subjected to a sequence of charging at $0.1 \mathrm{C}$ for $1 \mathrm{~h}$ followed by 0.5 -h rest on the Land-CT2001A battery test system until the potential reached $4.0 \mathrm{~V}\left(v s . \mathrm{Li}^{+} / \mathrm{Li}\right)$. The lithium-ion transference number was measured at room temperature using an electrochemical workstation. A constant voltage $(10 \mathrm{mV})$ was applied until the lithium symmetric cell exhibits a stable current value. The lithium transference number is calculated using Equation (1):

$t_{\mathrm{Li}^{+}}=\frac{I_{\mathrm{ss}}\left(\Delta V-I_{0} R_{0}\right)}{I_{0}\left(\Delta V-I_{\mathrm{ss}} R_{\mathrm{ss}}\right)}$,

where $\Delta V$ is the applied constant voltage $(10 \mathrm{mV}), I_{0}$ is the initial current, $I_{\mathrm{ss}}$ is the steady-state current, $R_{\mathrm{ss}}$ and $R_{0}$ are the inter- 
facial resistances after and before polarization, respectively.

Battery assembly and electrochemical characterization

Using PLC and PLB as the electrolytes, LFP as the cathode active material, and Li metal as the anode, the all-solid-state battery was assembled in 2032-coin cells. The cathode is composed of $80 \mathrm{wt} \% \mathrm{LFP}, 10 \mathrm{wt} \%$ polyvinylidene difluoride and $10 \mathrm{wt} \%$ Super-P. The all-solid-state batteries were assembled in an argon-filled glovebox. The measurements of cycle performance of all-solid-state batteries at 50 and $60^{\circ} \mathrm{C}$ were carried out in a voltage range of $2.8-4.0 \mathrm{~V}\left(v s . \mathrm{Li}^{+} / \mathrm{Li}\right)$. The performances at different rates were acquired from 0.1 to $1 \mathrm{C}$ at 50 and $60^{\circ} \mathrm{C}$. All of the above electrochemical measurements were carried out with the Land-CT2001A battery test system.

\section{RESULTS AND DISCUSSION}

In this work, the procedure for fabricating C-LALZO is illu- strated in Fig. 1. We first successfully developed C-LALZO with a cubic garnet structure using GO as the nucleation site under sol-gel conditions, for which the mechanism is briefly discussed in Fig. S1.

The XRD patterns in Fig. 2a verify the garnet crystalline structures of the C-LALZO and B-LALZO. Furthermore, as illustrated in Fig. 2f, g, the HRTEM further reveals that the CLALZO possesses a lattice spacing of $0.32 \mathrm{~nm}$, corresponding to the (411) crystallographic plane of the cubic phase LALZO, which further verifies the garnet crystalline structure of CLALZO. Moreover, XRD patterns of CPEs with C-LALZO and B-LALZO are presented in Fig. 2a. It can be observed that the peak intensity ratio of PEO in PLC is lower than that in PLB, which suggests that C-LALZO provides a more positive effect to reduce the crystallinity of PEO compared with B-LALZO. In addition, the XRD patterns of CPEs with different C-LALZO contents are presented in Fig. S2. With the increase of C-LALZO

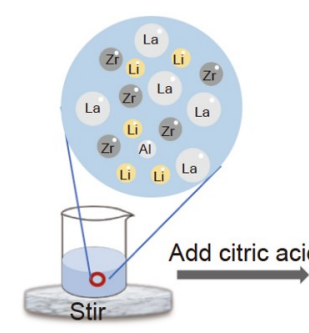

Salt solution

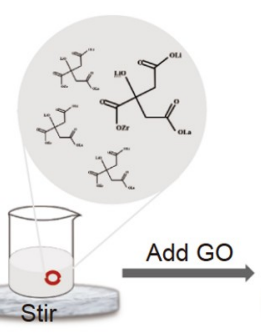

Sol

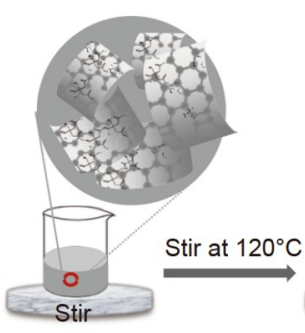

Sol with GO

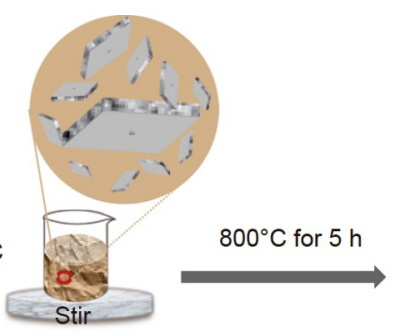

Precursor

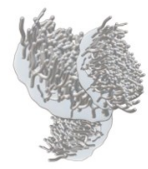

C-LALZO

Figure 1 Schematic diagram of the synthetic process of C-LALZO.
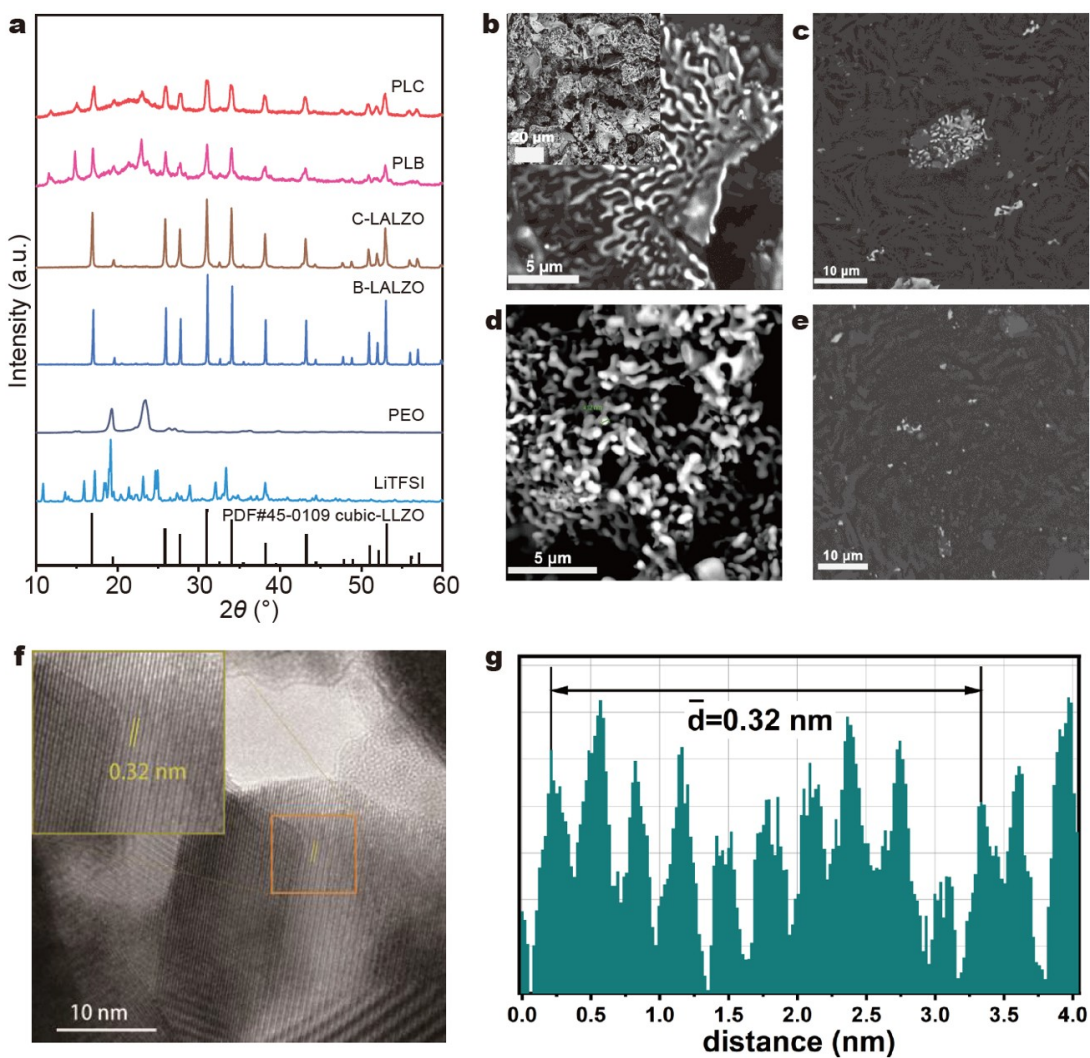

Figure 2 (a) XRD patterns of PEO, LiTFSI, LALZO and CPEs with $20 \mathrm{wt} \%$ C-LALZO and B-LALZO; SEM images of (b) C-LALZO, (c) PLC, (d) B-LALZO, and (e) PLB; (f) HRTEM and (g) average interplanar spacing of LALZO coral. 
content, the intensity of peaks increases gradually. Besides, the peak intensity ratio of $\mathrm{PEO}$ decreases in the $\mathrm{CPE}$, which indicates that the C-LALZO filler effectively reduces the crystallinity of PEO. As presented in Fig. 2a, the C-LALZO is in the form of $3 \mathrm{D}$ continuous coral, which serves as a fast lithium-ion transportation channel in the CPE to improve the ionic conductivity [44]. However, the LALZO branches are partly aggregated (Fig. 2d). It can be observed in Fig. 2c, e that the garnet CLALZO and B-LALZO particles are embedded in the PEO electrolyte. Compared with B-LALZO, C-LALZO forms $1 \mathrm{D}$ and $2 \mathrm{D}$ continuous fast lithium-ion conduction channels in PEO, which can promote the ionic transportation of the CPE.

The ionic conductivity $(\sigma)$ is calculated via the following Equation (2) [48]:

$\sigma=L /(R S)$,

where $S$ is the area of electrolyte, and $L$ the thickness of electrolyte. $R$ is obtained by EIS measurement with symmetric cells of the electrolyte sandwiched by two SS electrodes. The resistance $R$ is the total resistance of charge transfer and ohmic resistance, and the value of $R$ was obtained by adopting the intercept of arc and abscissa axis. Electrolytes with a thickness of $\sim 400 \mu \mathrm{m}$ are adopted for the ionic conductivity measurements to ensure precise thickness measurements. The Nyquist plots of PLC and PLB for evaluating the ionic conductivity are shown in Fig. 3a. The EIS of pure PEO electrolyte is also presented in Fig. S3. By comparing the ionic conductivity of PLC electrolytes with various C-LALZO contents (Fig. 3b), the PLC with $20 \mathrm{wt} \%$ C-LALZO has an optimal ionic conductivity. Therefore, the ionic conductivity of PLB with $20 \mathrm{wt} \%$ B-LALZO is also listed in Fig. $3 \mathrm{~b}$ for comparison. The fitted equivalent circuit model is shown in the inset of Fig. 3a, c. The small intercept corresponds to the electrolyte resistance $\left(R_{\Omega}\right)$, the depressed semicircle is related to the charge transfer resistance $\left(R_{\mathrm{ct}}\right)$ and the constant phase element, and the inclined line at low frequencies represents the Warburg impedance due to the diffusion of lithium ions in the electrode $\left(Z_{\mathrm{w}}\right)$. The results in Fig. $3 \mathrm{~b}$ show that the garnet coral-like filler can enhance the ionic conductivity to a larger degree than the branch-like counterpart. Besides, the results of EIS also verify the conjecture from the test results of $\mathrm{XRD}$ in Fig. 2a. The higher ionic conductivity is attributed to their continuous unique coral-like structure with $1 \mathrm{D}$ LALZO nanowires seated on a $2 \mathrm{D}$ LALZO plate, which can promote ion transportation and provide fast ion transportation channels. Fig. $3 \mathrm{c}$ presents the impedance spectra of PLC at different temperatures from 25 to $70^{\circ} \mathrm{C}$. The linear relationship (Fig. 3d) between Li-ion conductivity and temperature conforms to the Arrhenius equation [49]. Besides, the lithium-ion transference number was measured at $60^{\circ} \mathrm{C}$ by an electrochemical workstation (Fig. S4). The calculated value of $t_{\mathrm{Li}^{+}}$of the PLC is 0.26 .

As revealed in Fig. 4a, the enhanced peaks at 829 and $1080 \mathrm{~cm}^{-1}$ appear in PLC CPE compared with that of PLB, corresponding to the $\mathrm{C}-\mathrm{N}$ functional group [50]. The $\mathrm{C}-\mathrm{N}$ group comes from the result of the interactions between the carbon of PEO and nitrogen-containing functional groups. Because of the existence of ceramic LALZO, TFSI ${ }^{-}$anion could be fixed by $\mathrm{PEO}$ polymer chain, thus inducing the uniform distribution of space charge, which is beneficial to inhibiting the growth of lithium dendrite [51]. The GITT experiments were performed at $60^{\circ} \mathrm{C}$ to further solidify the results of EIS and FTIR. The corresponding transient charge potential profiles and the
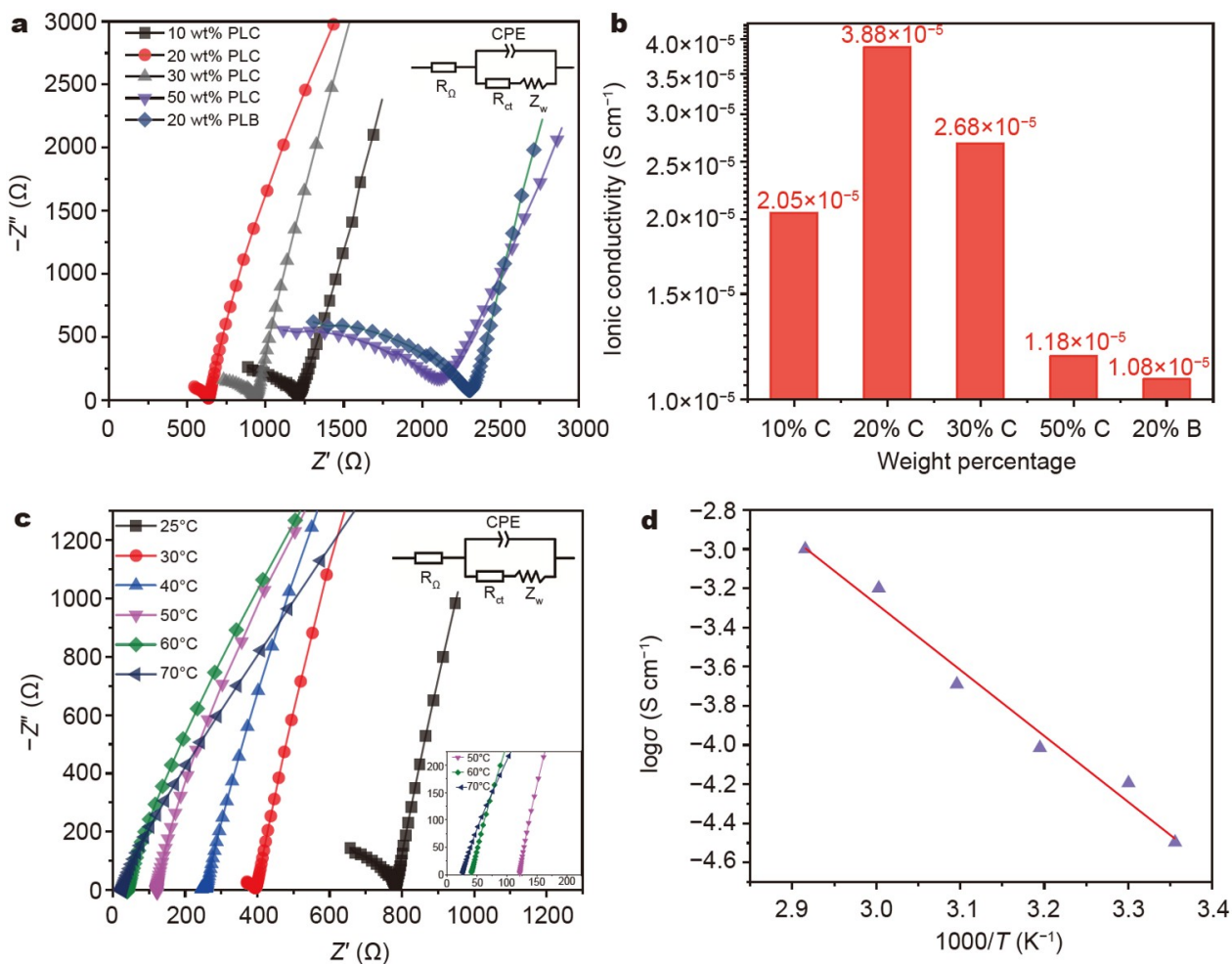

Figure 3 (a) EIS and (b) calculated ionic conductivity of CPE with different LALZO contents at $25^{\circ} \mathrm{C}$ (C and B correspond to PLC and PLB, respectively); (c) EIS and (d) Arrhenius plot of the PLC (20 wt\% C-LALZO) at elevated temperatures (from 20 to $70^{\circ} \mathrm{C}$ ) (the inset figure in (c) is an enlarged view of the high frequency range of impedance under 50,60 , and $70^{\circ} \mathrm{C}$ ). 

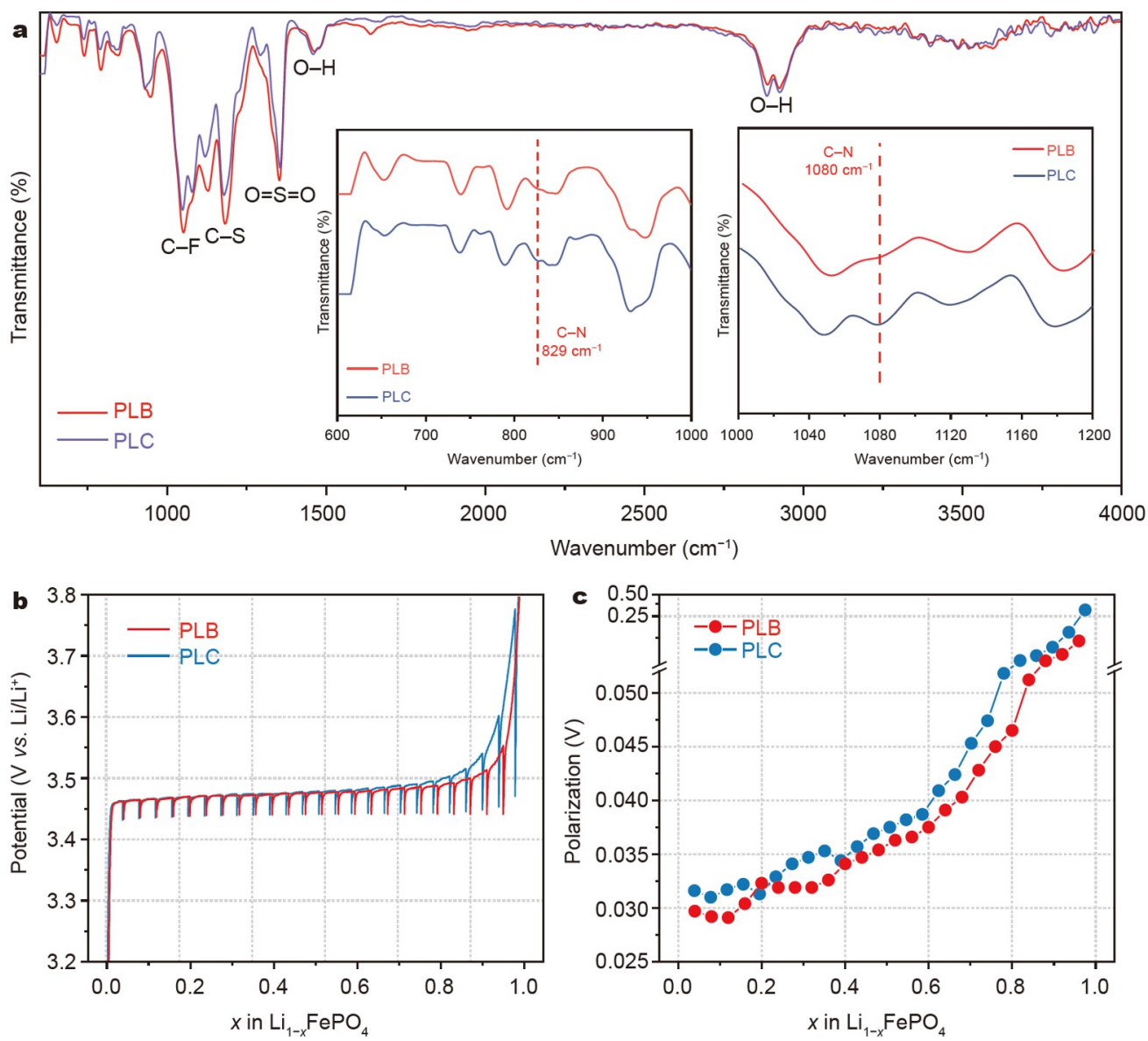

Figure 4 (a) FTIR of PLB and PLC (inset: details of plots at around 829 and $1080 \mathrm{~cm}^{-1}$ ); (b) GITT profiles, and (c) the polarization of PLB and PLC at different states of the charging process.

calculated polarization are presented in Fig. $4 \mathrm{~b}, \mathrm{c}$, respectively. As shown in Fig. 4 b, the profile of the battery with PLC electrolyte delivers smaller overpotentials than that of PLB electrolyte, indicating a higher $\mathrm{Li}^{+}$diffusion coefficient. PLC electrolyte displays lower polarization values than those of PLB electrolyte at various potentials of the charging process (Fig. 4c), which suggests faster $\mathrm{Li}^{+}$diffusion kinetics in the PLC electrolyte than in the PLB electrolyte [52].

The stability of the composite solid electrolyte against Li metal was evaluated using $\mathrm{Li}$ symmetric cells. The $\mathrm{Li} / \mathrm{PLC} / \mathrm{Li}$ and $\mathrm{Li} /$ PLB/Li symmetric cells were charged and discharged for $1 \mathrm{~h}$ under current densities of 0.02 and $0.05 \mathrm{~mA} \mathrm{~cm}^{-2}$ at $60^{\circ} \mathrm{C}$, respectively (Fig. 5a, b). After cycling for $1500 \mathrm{~h}$, the voltage hysteresis of the symmetric cell with PLC can still remain stable at about $100 \mathrm{mV}$. However, abrupt voltage drops (indicated by the arrow in Fig. 5a) are observed in the later cycling period of $\mathrm{Li} / \mathrm{PLB} / \mathrm{Li}$ due to a short circuit of the cell, which suggests undesired deposition of lithium. This result confirms that the PLC CPE is more able to block the growth of lithium dendrite than the PLB electrolyte. Furthermore, when the current density is increased to $0.05 \mathrm{~mA} \mathrm{~cm}^{-2}$, voltage polarization of $\mathrm{Li} / \mathrm{PLB} / \mathrm{Li}$ cells rapidly increased. This unfavorable cycling behavior is attributed to the low ionic conductivity of PLB, which leads to undesired lithium deposition. The polarization voltage of $\mathrm{Li} /$ PLC/Li cells remains at $250 \mathrm{mV}$, suggesting excellent cycling stability and superior capability to suppress lithium dendrite growth. Besides, to further confirm the superior positive effect of PLC to inhibit lithium dendrite growth, the surface morphology of lithium anode from $\mathrm{Li} / \mathrm{Li}$ symmetric cells after cycling for $1500 \mathrm{~h}$ is presented in Fig. $5 \mathrm{c}$, d. The lithium anode in symmetric cells with PLC electrolyte exhibits a smoother surface than that with the PLB electrolyte.

All-solid-state LFP/PLB/Li and LFP/PLC/Li batteries were assembled to verify the electrochemical advantages of C-LALZO structure. Fig. $6 \mathrm{a}, \mathrm{b}$ show the cycling performance at $0.1 \mathrm{C}$ at 50 and $60^{\circ} \mathrm{C}$, respectively. The assembled LFP/PLC/Li exhibits an initial discharge specific capacity of $159.8 \mathrm{~mA} \mathrm{hg}^{-1}$, which remains at $145.6 \mathrm{~mA} \mathrm{~h} \mathrm{~g}^{-1}$ after 80 cycles with a capacity retention rate of $91.1 \%$. However, LFP/PLB/Li exhibits a lower capacity retention rate of $86.3 \%$. Since the operating temperature makes a great difference to the performance of all-solid-state batteries, the performance of all-solid-state batteries at a lower temperature was measured. At $50^{\circ} \mathrm{C}$, the discharge capacity of the LFP/PLC/Li cell exhibits $135.5 \mathrm{~mA} \mathrm{~h} \mathrm{~g}^{-1}$ after 70 cycles with a capacity retention ratio of $93.3 \%$ (Fig. $6 \mathrm{a}$ ), which is much higher than that of the LFP/PLB/Li cells, $125.6 \mathrm{~mA} \mathrm{~h} \mathrm{~g}^{-1}$ after 70 cycles with a capacity retention ratio of $86.5 \%$. The results suggest that all-solid-state batteries with PLC can work at a lower temperature. The significant promotion of electrochemical performance is attributed to the high conductivity of PLC ensuring fast ion transport and stable interfacial contact between electrodes and PLC in the LFP/PLC/Li cells. 

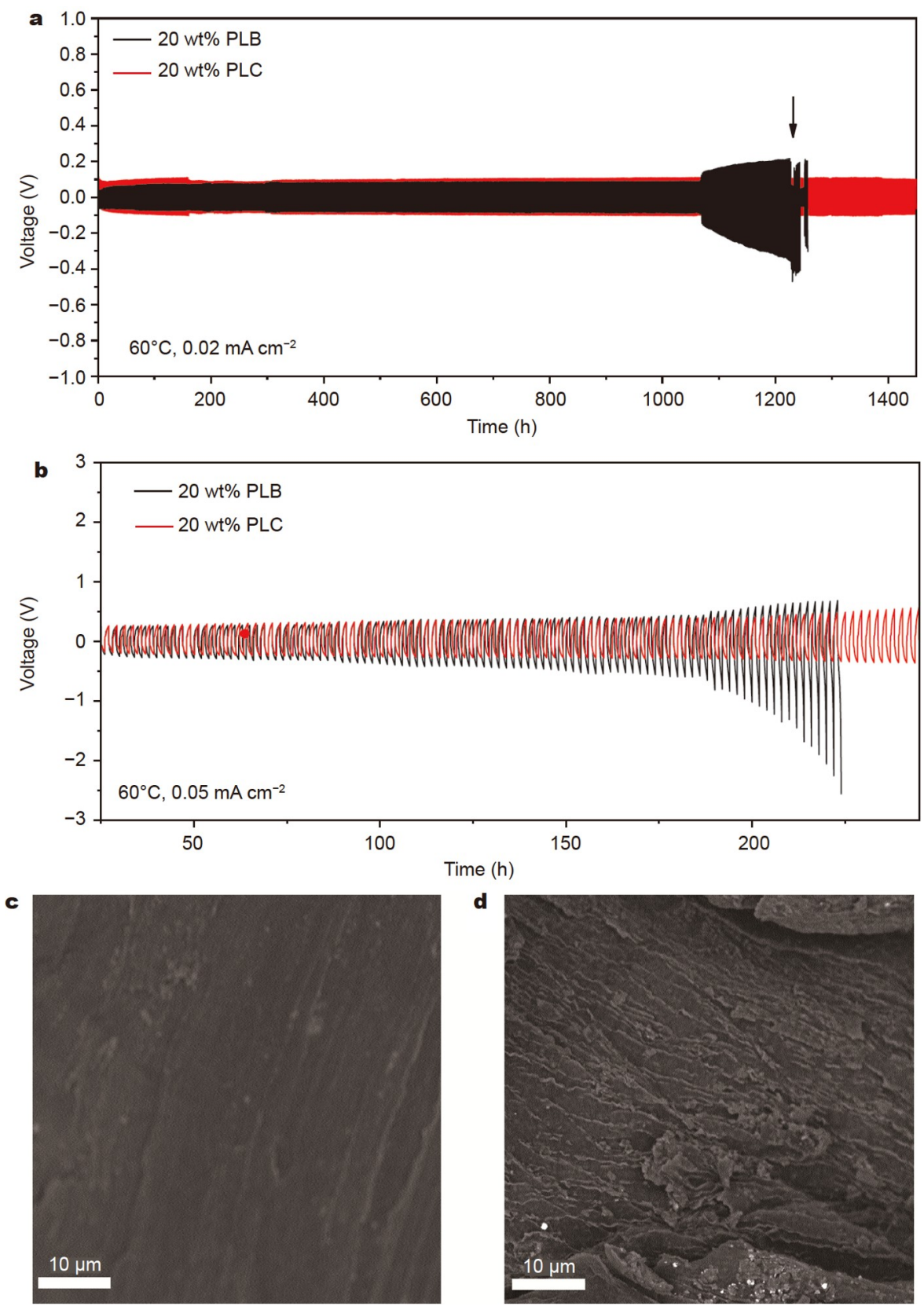

Figure 5 Voltage profiles of the lithium plating/stripping cycling at current densities of (a) 0.02 and (b) $0.05 \mathrm{~mA} \mathrm{~cm}{ }^{-2}$ at $60^{\circ} \mathrm{C}$; SEM images of Li-metal anode after cycling in (c) Li/PLC/Li and (d) Li/PLB/Li symmetric cells.

The rate performances of the assembled all-solid-state batteries with PLC and PLB CPE at various rates from 0.1 to $1 \mathrm{C}$ at 50 and $60^{\circ} \mathrm{C}$ are presented in Fig. $6 \mathrm{c}$, d, respectively. The discharge specific capacities of the LFP/PLC/Li cell cycled at $60^{\circ} \mathrm{C}$ at $0.1,0.2,0.5$ and $1.0 \mathrm{C}$ are 158.7, 155.4, 150.5, and $143.9 \mathrm{~mA} \mathrm{~h} \mathrm{~g}^{-1}$, respectively. The discharge specific capacities of the $\mathrm{LFP} / \mathrm{PLC} / \mathrm{Li}$ cell cycled at $50^{\circ} \mathrm{C}$ at $0.1,0.2,0.5$ and $1.0 \mathrm{C}$ are $153.2,150.8,146.5$, and $99.3 \mathrm{~mA} \mathrm{~h} \mathrm{~g}^{-1}$, respectively. These specific capacities at different rates are higher than those of batteries with the PLB CPE at corresponding rates, indicating the fast ion transportation of PLC, which is consistent with the higher $\mathrm{Li}^{+}$ diffusion coefficient and smaller overpotential shown in Fig. 6 b. The discharge specific capacity recovers to $153.7 \mathrm{mAhg}^{-1}$ at
$0.2 \mathrm{C}, 60^{\circ} \mathrm{C}$ and $150.2 \mathrm{~mA} \mathrm{~h} \mathrm{~g}^{-1}$ at $0.2 \mathrm{C}, 50^{\circ} \mathrm{C}$ after cycling at $1 \mathrm{C}$, which suggests the assembled all-solid-state LFP/PLC/Li batteries possess excellent stability.

The LSV in Fig. S5 presents the decomposition voltage of PLC and PLB, which reveals that PLC possesses a wider electrochemical window than PLB. Therefore, high voltage cathodes (NCM and LCO) were adopted to assemble all-solid-state batteries. The all-solid-state batteries using NCM111 and LCO cathodes exhibit excellent cycling stability at $0.1 \mathrm{C}\left(60^{\circ} \mathrm{C}\right.$, Fig. 6e). Besides, as shown in Fig. $6 \mathrm{f}$ and Fig. S6, the presented smooth charge-discharge curves of NCM/PLC/Li and LCO/PLC/ Li cells indicate that no side reactions occur and PLC CPE exhibits excellent electrochemical stability at high voltages. 

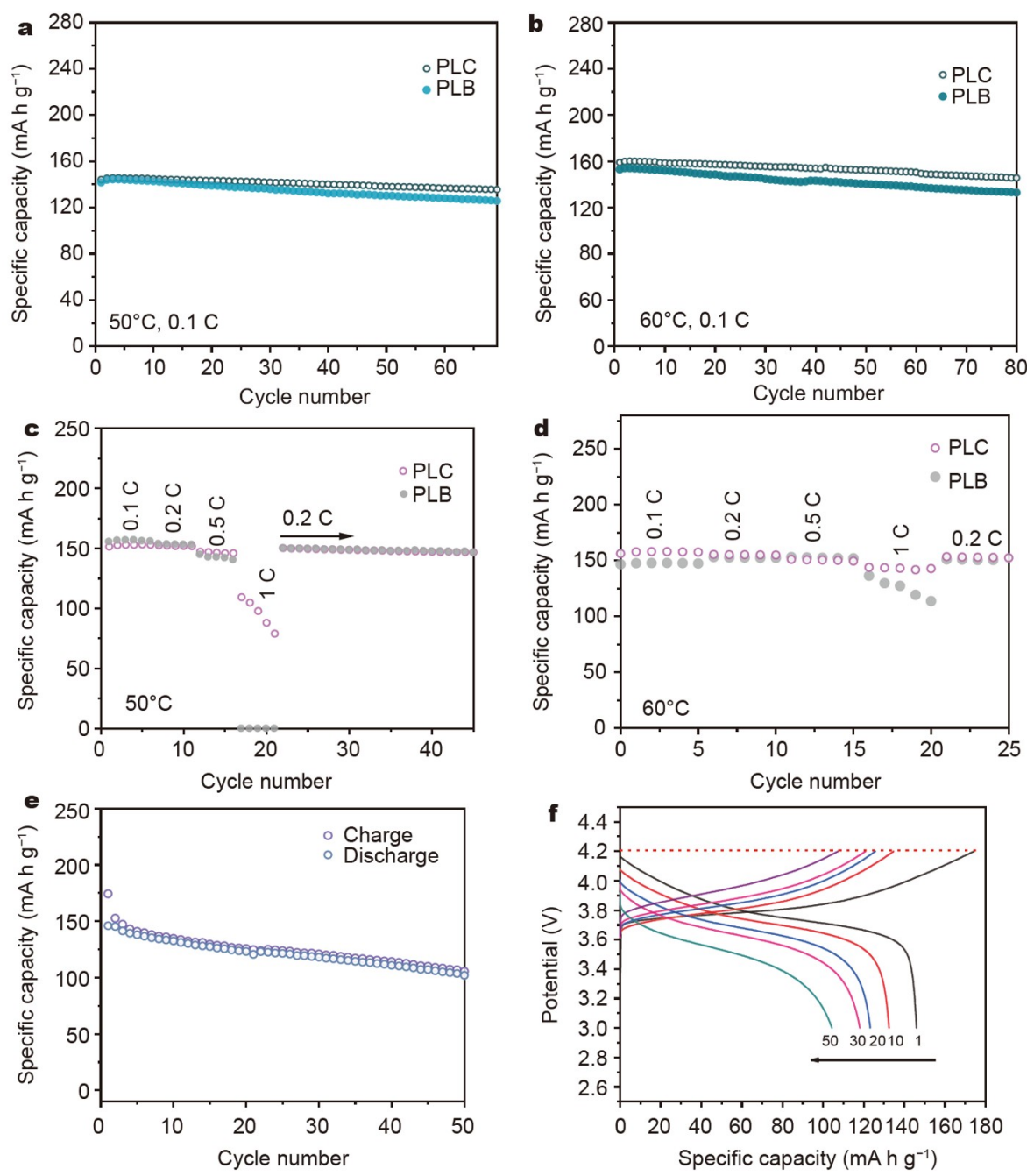

Figure 6 Electrochemical performances of LFP/PLC/Li and LFP/PLB/Li cells. Cycling performances of LFP/PLC/Li and LFP/PLB/Li cells at (a) 50 and (b) $60^{\circ} \mathrm{C}$. Rate performances of LFP/PLC/Li and LFP/PLB/Li cells at (c) 50 and (d) $60^{\circ} \mathrm{C}$. (e) Cycling performance and (f) charge-discharge voltage profiles of $\mathrm{NCM} 111 / \mathrm{PLC} / \mathrm{Li}$ at $0.1 \mathrm{C}\left(60^{\circ} \mathrm{C}\right)$.

\section{CONCLUSIONS}

In summary, this work provides a facile sol-gel method to fabricate C-LALZO, which has been proved to be an effective filler in the PEO matrix forming an advanced CPE. The incorporated C-LALZO increases the ionic conductivity and enhances the electrochemical properties of PEO. This novel composite solidstate electrolyte effectively inhibits the growth of lithium dendrite in a lithium symmetric battery during the cycling process for about $1500 \mathrm{~h}$ at $60^{\circ} \mathrm{C}$. The assembled all-solid-state LFP/PLC/ Li batteries exhibit a high specific capacity of $145.6 \mathrm{~mA} \mathrm{~h} \mathrm{~g}^{-1}$ after 80 cycles at $0.1 \mathrm{C}$ and $60^{\circ} \mathrm{C}$. Even at a lower temperature of $50^{\circ} \mathrm{C}$, a high specific capacity of $135.5 \mathrm{~mA} \mathrm{~h} \mathrm{~g}^{-1}$ was still retained after 70 cycles at $0.1 \mathrm{C}$. This work provides a facile sol-gel method to fabricate C-LALZO and develops an all-solid-state battery with a corresponding composite PEO electrolyte that exhibits good cycling stability and rate performance. Furthermore, it provides a reference for researchers to study the synergistic electrochemical effects of active ceramic fillers of various dimensions and morphologies in PEO.

Received 21 April 2021; accepted 23 June 2021; published online 26 August 2021
1 Goodenough JB, Park KS. The Li-ion rechargeable battery: A perspective. J Am Chem Soc, 2013, 135: 1167-1176

2 Armand M, Tarascon JM. Building better batteries. Nature, 2008, 451: 652-657

3 Sun Q, Li D, Cheng J, et al. Nitrogen-doped carbon derived from preoxidized pitch for surface dominated potassium-ion storage. Carbon, 2019, 155: 601-610

4 Li D, Dai L, Ren X, et al. Foldable potassium-ion batteries enabled by free-standing and flexible $\mathrm{SnS}_{2} @ \mathrm{C}$ nanofibers. Energy Environ Sci, 2021, 14: 424-436

5 Li J, Cai Y, Wu H, et al. Polymers in lithium-ion and lithium metal batteries. Adv Energy Mater, 2021, 11: 2003239

6 Huang Y, Duan J, Zheng X, et al. Lithium metal-based composite: An emerging material for next-generation batteries. Matter, 2020, 3: 10091030

7 Wu J, Yuan L, Zhang W, et al. Reducing the thickness of solid-state electrolyte membranes for high-energy lithium batteries. Energy Environ Sci, 2021, 14: 12-36

8 Aurbach D, Cohen Y. The application of atomic force microscopy for the study of Li deposition processes. J Electrochem Soc, 1996, 143: 3525-3532

9 Wu J, Liu S, Han F, et al. Lithium/sulfide all-solid-state batteries using sulfide electrolytes. Adv Mater, 2021, 33: 2000751

$10 \mathrm{Wu}$ J, Shen L, Zhang Z, et al. All-solid-state lithium batteries with 
sulfide electrolytes and oxide cathodes. Electrochem Energ Rev, 2021, 4: 101-135

11 Liu G, Weng W, Zhang Z, et al. Densified $\mathrm{Li}_{6} \mathrm{PS}_{5} \mathrm{Cl}$ nanorods with high ionic conductivity and improved critical current density for all-solidstate lithium batteries. Nano Lett, 2020, 20: 6660-6665

12 Liu G, Lu Y, Wan $\mathrm{H}$, et al. Passivation of the cathode-electrolyte interface for $5 \mathrm{~V}$-class all-solid-state batteries. ACS Appl Mater Interfaces, 2020, 12: 28083-28090

13 Huang Y, Chen B, Duan J, et al. Graphitic carbon nitride $\left(\mathrm{g}-\mathrm{C}_{3} \mathrm{~N}_{4}\right)$ : An interface enabler for solid-state lithium metal batteries. Angew Chem Int Ed, 2020, 59: 3699-3704

14 Zhai $\mathrm{P}$, Wang $\mathrm{T}$, Jiang $\mathrm{H}$, et al. 3D artificial solid-electrolyte interphase for lithium metal anodes enabled by insulator-metal-insulator layered heterostructures. Adv Mater, 2021, 33: 2006247

15 Tang Y, Zhang L, Chen J, et al. Electro-chemo-mechanics of lithium in solid state lithium metal batteries. Energy Environ Sci, 2021, 14: 602642

16 Sun C, Liu J, Gong Y, et al. Recent advances in all-solid-state rechargeable lithium batteries. Nano Energy, 2017, 33: 363-386

17 Banerjee A, Wang X, Fang C, et al. Interfaces and interphases in allsolid-state batteries with inorganic solid electrolytes. Chem Rev, 2020, 120: 6878-6933

18 Gao H, Huang $\mathrm{Y}$, Zhang Z, et al. $\mathrm{Li}_{6.7} \mathrm{La}_{3} \mathrm{Zr}_{1.7} \mathrm{Ta}_{0.15} \mathrm{Nb}_{0.15} \mathrm{O}_{12}$ enhanced UV-cured poly(ethylene oxide)-based composite gel polymer electrolytes for lithium metal batteries. Electrochim Acta, 2020, 360: 137014

19 Ao X, Wang X, Tan J, et al. Nanocomposite with fast $\mathrm{Li}^{+}$conducting percolation network: Solid polymer electrolyte with $\mathrm{Li}^{+}$non-conducting filler. Nano Energy, 2021, 79: 105475

20 Li S, Zhang SQ, Shen L, et al. Progress and perspective of ceramic/ polymer composite solid electrolytes for lithium batteries. Adv Sci, 2020, 7: 1903088

21 Quartarone E, Mustarelli P. Electrolytes for solid-state lithium rechargeable batteries: Recent advances and perspectives. Chem Soc Rev, 2011, 40: 2525-2540

22 Cheng SHS, He KQ, Liu Y, et al. Electrochemical performance of allsolid-state lithium batteries using inorganic lithium garnets particulate reinforced PEO/ $\mathrm{LiClO}_{4}$ electrolyte. Electrochim Acta, 2017, 253: 430438

23 Li X, Wang $\mathrm{D}$, Wang $\mathrm{H}$, et al. Poly(ethylene oxide) $-\mathrm{Li}_{10} \mathrm{SnP}_{2} \mathrm{~S}_{12}$ composite polymer electrolyte enables high-performance all-solid-state lithium sulfur battery. ACS Appl Mater Interfaces, 2019, 11: 2274522753

24 Zhu L, Zhu P, Yao S, et al. High-performance solid PEO/PPC/LLTOnanowires polymer composite electrolyte for solid-state lithium battery. Int J Energy Res, 2019, 43: 4854-4866

25 He KQ, Zha JW, Du P, et al. Tailored high cycling performance in a solid polymer electrolyte with perovskite-type $\mathrm{Li}_{0.33} \mathrm{La}_{0.557} \mathrm{TiO}_{3}$ nanofibers for all-solid-state lithium ion batteries. Dalton Trans, 2019, 48: 3263

26 Capiglia C. Effects of nanoscale $\mathrm{SiO}_{2}$ on the thermal and transport properties of solvent-free, poly(ethylene oxide) (PEO)-based polymer electrolytes. Solid State Ion, 1999, 118: 73-79

27 Kim JW, Ji KS, Lee JP, et al. Electrochemical characteristics of two types of PEO-based composite electrolyte with functional $\mathrm{SiO}_{2}$. J Power Sources, 2003, 119-121: 415-421

28 Xi G, Xiao M, Wang S, et al. Polymer-based solid electrolytes: Material selection, design, and application. Adv Funct Mater, 2021, 31: 2007598

29 Dissanayake MAKL, Jayathilaka PARD, Bokalawala RSP, et al. Effect of concentration and grain size of alumina filler on the ionic conductivity enhancement of the $(\mathrm{PEO})_{9} \mathrm{LiCF}_{3} \mathrm{SO}_{3}: \mathrm{Al}_{2} \mathrm{O}_{3}$ composite polymer electrolyte. J Power Sources, 2003, 119-121: 409-414

30 D'Epifanio A, Serraino Fiory F, Licoccia S, et al. Metallic-lithium, $\mathrm{LiFePO}_{4}$-based polymer battery using $\mathrm{PEO}-\mathrm{ZrO}_{2}$ nanocomposite polymer electrolyte. J Appl Electrochem, 2004, 34: 403-408

31 Zheng J, Tang $\mathrm{M}$, Hu YY. Lithium ion pathway within $\mathrm{Li}_{7} \mathrm{La}_{3} \mathrm{Zr}_{2} \mathrm{O}_{12}-$ polyethylene oxide composite electrolytes. Angew Chem Int Ed, 2016, 55: $12538-12542$

32 Guo Q, Xu F, Shen L, et al. Poly(ethylene glycol) brush on $\mathrm{Li}_{6.4} \mathrm{La}_{3}-$
$\mathrm{Zr}_{1.4} \mathrm{Ta}_{0.6} \mathrm{O}_{12}$ towards intimate interfacial compatibility in composite polymer electrolyte for flexible all-solid-state lithium metal batteries. J Power Sources, 2021, 498: 229934

33 Wang C, Yang Y, Liu X, et al. Suppression of lithium dendrite formation by using LAGP-PEO (LiTFSI) composite solid electrolyte and lithium metal anode modified by PEO (LiTFSI) in all-solid-state lithium batteries. ACS Appl Mater Interfaces, 2017, 9: 13694-13702

34 Zhai $\mathrm{H}, \mathrm{Xu} \mathrm{P}$, Ning M, et al. A flexible solid composite electrolyte with vertically aligned and connected ion-conducting nanoparticles for lithium batteries. Nano Lett, 2017, 17: 3182-3187

35 Chen L, Li Y, Li SP, et al. PEO/garnet composite electrolytes for solidstate lithium batteries: From "ceramic-in-polymer" to "polymer-inceramic". Nano Energy, 2018, 46: 176-184

36 Zhao Y, Huang Z, Chen S, et al. A promising PEO/LAGP hybrid electrolyte prepared by a simple method for all-solid-state lithium batteries. Solid State Ion, 2016, 295: 65-71

37 Wang J, Yang J, Shen L, et al. Synergistic effects of plasticizer and 3D framework toward high-performance solid polymer electrolyte for room-temperature solid-state lithium batteries. ACS Appl Energy Mater, 2021, 4: 4129-4137

38 Wan Z, Lei D, Yang W, et al. Low resistance-integrated all-solid-state battery achieved by $\mathrm{Li}_{7} \mathrm{La}_{3} \mathrm{Zr}_{2} \mathrm{O}_{12}$ nanowire upgrading polyethylene oxide (PEO) composite electrolyte and PEO cathode binder. Adv Funct Mater, 2019, 29: 1805301

39 Gong Y, Fu K, Xu S, et al. Lithium-ion conductive ceramic textile: A new architecture for flexible solid-state lithium metal batteries. Mater Today, 2018, 21: 594-601

40 Tao X, Liu Y, Liu W, et al. Solid-state lithium-sulfur batteries operated at $37^{\circ} \mathrm{C}$ with composites of nanostructured $\mathrm{Li}_{7} \mathrm{La}_{3} \mathrm{Zr}_{2} \mathrm{O}_{12} /$ carbon foam and polymer. Nano Lett, 2017, 17: 2967-2972

41 Liu W, Liu N, Sun J, et al. Ionic conductivity enhancement of polymer electrolytes with ceramic nanowire fillers. Nano Lett, 2015, 15: 27402745

42 Zhang X, Xie J, Shi F, et al. Vertically aligned and continuous nanoscale ceramic-polymer interfaces in composite solid polymer electrolytes for enhanced ionic conductivity. Nano Lett, 2018, 18: 3829-3838

43 Song $\mathrm{S}$, Wu Y, Tang W, et al. Composite solid polymer electrolyte with garnet nanosheets in poly(ethylene oxide). ACS Sustain Chem Eng, 2019, 7: 7163-7170

44 Bae J, Li Y, Zhang J, et al. A 3D nanostructured hydrogel-frameworkderived high-performance composite polymer lithium-ion electrolyte. Angew Chem Int Ed, 2018, 57: 2096-2100

$45 \mathrm{Fu} \mathrm{KK}$, Gong Y, Dai J, et al. Flexible, solid-state, ion-conducting membrane with 3D garnet nanofiber networks for lithium batteries. Proc Natl Acad Sci USA, 2016, 113: 7094-7099

46 Xie H, Yang C, Fu KK, et al. Flexible, scalable, and highly conductive garnet-polymer solid electrolyte templated by bacterial cellulose. Adv Energy Mater, 2018, 8: 1703474

47 Lu Y, Huang X, Song Z, et al. Highly stable garnet solid electrolyte based Li-S battery with modified anodic and cathodic interfaces. Energy Storage Mater, 2018, 15: 282-290

48 Tarascon JM, Armand M. Issues and challenges facing rechargeable lithium batteries. Nature, 2001, 414: 359-367

49 Wang Y, Zhong WH. Development of electrolytes towards achieving safe and high-performance energy-storage devices: A review. ChemElectroChem, 2015, 2: 22-36

50 Zhang $\mathrm{X}$, Liu T, Zhang $\mathrm{S}$, et al. Synergistic coupling between $\mathrm{Li}_{6.75} \mathrm{La}_{3-}$ $\mathrm{Zr}_{1.75} \mathrm{Ta}_{0.25} \mathrm{O}_{12}$ and poly(vinylidene fluoride) induces high ionic conductivity, mechanical strength, and thermal stability of solid composite electrolytes. J Am Chem Soc, 2017, 139: 13779-13785

51 Zhao CZ, Zhang XQ, Cheng XB, et al. An anion-immobilized composite electrolyte for dendrite-free lithium metal anodes. Proc Natl Acad Sci USA, 2017, 114: 11069-11074

52 Li D, Chen L, Chen L, et al. Potassium gluconate-derived N/S co-doped carbon nanosheets as superior electrode materials for supercapacitors and sodium-ion batteries. J Power Sources, 2019, 414: 308-316

Acknowledgements This work was supported by the School Research 
Startup Expenses of Harbin Institute of Technology (Shenzhen) (DD29100027), the National Natural Science Foundation of China (52002094), China Postdoctoral Science Foundation (2019M661276), Guangdong Basic and Applied Basic Research Foundation (2019A1515110756), and the High-level Talents Discipline Construction Fund of Shandong University (31370089963078).

Author contributions $\mathrm{Ci} \mathrm{L}$ and Li D conceived and supervised this project. Cheng $J$ and Hou $G$ designed the experiments. Cheng $J$ carried out the preparation of electrolyte materials, material characterization, assembly of batteries, electrochemical measurements, and data analysis. Sun Q and Chen Q performed some data analysis and offered helpful suggestions. Li J and Zeng $\mathrm{Z}$ assisted in the preparation of electrolyte materials. Cheng J and Li D co-wrote the paper. Li K, Yuan Q, Wang J, and Ci L revised the manuscript. All authors contributed to the general discussion.

Conflict of interest The authors declare that they have no conflict of interest.

Supplementary information Supporting data are available in the online version of the paper.

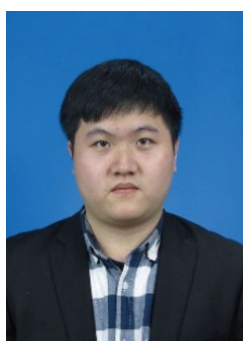

Jun Cheng is currently a doctoral candidate at the School of Materials Science and Engineering, Harbin Institute of Technology (Shenzhen). He received his Master's degree under the supervision of Prof. Lijie Ci at the Materials Science and Engineering Institute, Shandong University. His current research focuses on solid state batteries.

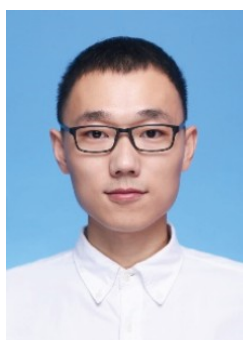

Deping $\mathbf{L i}$ is currently an assistant professor at the School of Materials Science and Engineering, Harbin Institute of Technology (Shenzhen). He received his $\mathrm{PhD}$ degree in materials science and engineering from Shandong University under the supervision of Prof. Lijie $\mathrm{Ci}$ in 2019. His current research focuses on nextgeneration energy storage applications like solid-state batteries, potassium-ion batteries, and lithium-air batteries.

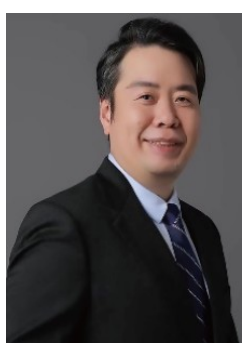

Lijie Ci is currently a full professor at the School of Materials Science and Engineering, Harbin Institute of Technology (Shenzhen). He received his $\mathrm{PhD}$ degree in mechanical engineering from Tsinghua University. He had been a researcher at the Institute of Physics, Chinese Academy of Sciences, Ecole Central Paris in France, the Max Planck Institute for Metals in Germany, Rensselaer Polytechnic Institute, Rice University and Samsung Cheil Industry (San Jose $\mathrm{Lab}$ ) in USA. Before he joined Harbin Institute of Technology (Shenzhen), he was a professor at Shandong University. His scientific interest focuses on carbon-based materials and energy storage devices.

\section{一种用于高性能聚环氧乙烷基全固态电池的新型珊} 瑚状石榴石

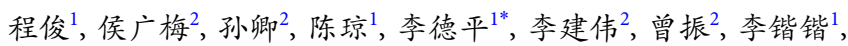
袁群惠 ${ }^{1}$, 王家钧 ${ }^{3}$, 慈立杰 ${ }^{1,2 *}$

摘要 锂金属电池被认为是最有前景的下一代储能设备之一，但是锂 金属电池的安全性问题以及锂枝晶生长问题严重阻碍了它的实用化进 程. 固态电解质可以有效解决这一安全性问题, 表现出能够抑制锂枝晶 生长的巨大潜力, 并因此受到大家的关注. 其中聚环氧乙烷( $\mathrm{PEO}$ )基固 态电解质由于具有较高的安全性以及出色的柔韧性, 被认为是一类非 常有应用前景的固态电解质. 但是, 其固有的半结晶特性以及较差的力 学性能导致它们在室温下的离子电导率较低, 并且在高温下不能有效 地抑制锂枝晶生长. 为改善上述问题, 本文设计并合成了一种新型的珊 瑚状 $\mathrm{Li}_{6.25} \mathrm{Al}_{0.25} \mathrm{La}_{3} \mathrm{Zr}_{2} \mathrm{O}_{12}(\mathrm{C}-\mathrm{LALZO})$ 活性陶瓷填料来增强PEO聚合物电 解质, 制备得到的复合固态电解质 (PLC) 表现出更高的离子电导率和机 械强度, 保证了锂金属的均匀沉积/剥离. 采用PLC的锂对称电池在 $60^{\circ} \mathrm{C}$ 下循环 1500 小时不发生短路. 组装得到的 $\mathrm{LiFePO}_{4} / \mathrm{PLC} / \mathrm{Li}$ 全固态电池 在 60 和 $50^{\circ} \mathrm{C}$ 时均有出色的循环稳定性. 这项工作表明, 通过调节填料的 微观结构(如C-LALZO结构), 可以有效地改善复合电解质的电化学性 能. 